\title{
黒毛和種下㢉症子牛の血清脂質抒よび 膵臓性血清酵素に関する検討
}

\author{
岡田啓司* 高橋千賀子' ${ }^{1}$ 渥美孝雄 ${ }^{1}$ \\ 菊地 薰 ${ }^{2}$ 小島佳岳 ${ }^{2}$ 南舘君夫 ${ }^{1)}$ \\ 岩手大学農学部附属家畜病院、宮城県農業共済組合連合会家畜診療研修所 ${ }^{1}$ 、 \\ 同筑館家畜診療所 ${ }^{21}$
}

\begin{abstract}
要 旨 出生後 1 日ないし14週龄の黒毛和種における下痢症子牛31頭（これらのうち白痢を呈したも

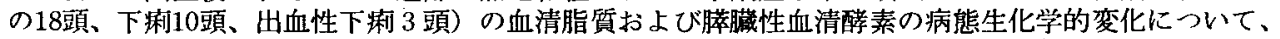
血清トリグリセライド（T G）濃度を基にして比較検討した。 T G濃度の低い白峲子牛（6 頭）では、 総コレステロール（Ｃ）、遊離脂肪酸（F F A ）等の脂質成分の多くと、アルブミンおよびグルコー ス（Glu）が低值を示し、低エネルギーで体力の消耗していることが示唆された。T G 濃度の高い白㢉 子牛（6頭）では、対照としての健康子牛（74頭）の血液成分とほとんど差が認められず、脂質の吸収 が過剩になっていることが示唆された。T Gの低い下痢子牛（6頭）では、他の脂質成分も低倠を示し、 腸管の吸收能が低下しているものと考えられた。T Gの高い下莉子牛（4頭）では、他の脂質成分が低 值を、F F AおよびAmy が高值を示した。このうち、T Gが著しく高かった 1 頭は発育不良を呈した。 出血性下痢の 3 頭では、共通して T Gが高値を示し、1 頭は整死し、他の 2 頭は発育不良を呈した。こ のうち経過を連続的に観察した発育不良の 1 頭で $\mathrm{T} \mathrm{G}$ 等の脂質成分のほかに、Amy、Lip 活性值が高 值を示し、急性膵炎が疑われた。以上の知見から、白痢や出血性下痢を含む子牛の下痢症では、T Gお よび Glu 濃度の低下とF F A 濃度の上昇が認められ、エネルギーが消耗している子牛と、T G 濃度が高 值を示し、脂質の代謝異常が認められた子牛に分けることができた。後者には Amy および Lip 活性值 が高値を示し、急性膵炎が関与した症例が含まれ、予後の悪い傾向が認められた。—キーワード：黒 毛和種、子牛、下痢、脂質、急性膵炎
\end{abstract}

東北家畜臨床研誌 $15(1): 15-21,1992$

\begin{abstract}
Changes of Serum Lipid Concentration and Pancreatic Enzyme Activity on the Diarrhea Calves of Japanese Black Cattle. Keiji Okada*, C. Takahashi ${ }^{1)}$, T. Atsumi ${ }^{1)}$, K. Kikuchi ${ }^{2)}$, Y. Ojima ${ }^{2)}$ and K. Minamidate ${ }^{1)}$ (Veterinary Teaching Hospital, University of Iwate, Miyagi Veterinary Clinical Training Center ${ }^{1)}$, Tsukidate Veterinary Clinic ${ }^{21}$ )

The clinico-biochemical examinations, especially analyses of serum lipid components were performed on the 18 white scoured calves, 10 diarrhea calves, 3 bleeding diarrhea calves of Japanese Black Cattle 0 to 14 weeks of age. The values obtained were compared with those from the 74 healthy calves of the same age range. In the group of white scoured calves, the value of TG was closely related to the other hemological values. Namely, in the 6 calves with a low level of TG, the values of the other lipid components and glucose showed lower levels than the healthy calves. In addition, in the remaining 6 calves with a high level of TG, the values of other blood components were similar to the healthy calves. In the 6 cases of diarrhea with a low level of TG, other lipid components levels were similar to the group of white scour with a low TG. On the other hand, in the remaining 4 cases having diarrhea with a high level of TG, the values of FFA, amylase and lipase were higher, and other lipid components lower. In all bleeding diarrhea calves, the value of TG was higher. One of them died, and other 2 calves did not mature. It was noticed in one of the not fully grown calves that the values of amylase and lipase were higher, and other enzymes showed abnormal levels. From the results obtained, this calf was diagnosed as having acute pancreatitis. - Key Words : Japanese Black Cattle, calf, diarrhea, lipids components, acute pancreatitis.
\end{abstract}

Tohoku J. Vet. Clin. 15(1): 15-21, 1992

黒毛和種における子牛の下痢症は、発生率の高さ11,23)、 発育への悪影響および死の転㷌をとる場合の多いこと11) 等から、その予防と治療には、繁殖牛飼養農家や臨床獣
医師の間で高い関心が寄せられている。黒毛和種子牛は、 同一環境下で飼養された他品種の子牛に比べて下痢発症 率が著しく高く17)、黒毛和種の下利に関する多くの総説

Accepted 30 March 1992 / Received 24 February 1992

* Correspondence to : Veterinary Teaching Hospital, Faculty of Agriculture University of Iwate, Morioka, Iwate 020（宁020 岩手県盛岡市上田 3-18-8) 
が記されている6,9,16,17)。下浰の病態生化学について は、脱水との関連について多くの研究があり 4, 5,6,13,21)、 白痢と胆汁酸の関連についても報告7さされている。また 慢性の下症症は消耗性疾患に移行することが少なくなく、 そのようなホルスタイン種子牛に対する脂肪乳剂の補液 の有効性 ${ }^{12)}$ が報告されているが、黑毛和種子牛について は見られない。

本報告では、黒毛和種における子牛の下痢症の病態を 明らかにする目的で、下症症子牛の血清脂質成分および 膵臓性血清酵素について検討した。

\section{材料と方法}

\section{1 ，供践牛}

供試牛は出生後 1 日から14週龄の黒毛和種子牛31頭を 用いた。これらの下痢の症状別頭数は、白痢子牛が 18 頭、 色調が正常便と変わらない下痢（下痢）子牛が10頭、出 血性下痢子牛が 3 頭であった。また対照として、同一週 齢の臨床的に健康な子牛74頭を用いた。

白痢子牛18頭はトリグリセライド（T G）の濃度によ り、30mg / dl以下をL T G群、31 60mg / dlをMT G群
および $61 \mathrm{mg} / d \ell$ 以上をH T G 群に分類した。また下㢉子 牛10頭は T Gの濃度により、32mg / d 以以下 L T G 群と、 $54 \mathrm{mg} / d \ell$ 以上のH T G 群の 2 群に分類した。なお病牛は 初診日を第 1 病日とした。

\section{2. 血液の探取と処理}

採血は早朝空腹時の実施が困難であったため、病牛は 原則として午前中の初診時に、健康牛は午前 10 時から 12 時の一定時 $1 ， 10 、 15)$ に、頸静脈よりフッ化ナトリウム添 加および無添加真空採血管で行い、可及的速やかに血漿 および血清を分離後、 $4{ }^{\circ} \mathrm{C}$ に保存した。血液検査は採血 当日または翌日に行った。症例Cのリパーゼ（Lip）は - $20^{\circ} \mathrm{C}$ 凍結保存した血清により後日測定した。

\section{3 、検查項目亡方法}

血液検查項目および方法は表 1 に示した。また症例 C のリポタンパクの分類は Fredrickson らの方法3，8，141

で、尿検査はNマルチスティックにより行った。

\section{4. 統計処理}

統計処理は Bartlett 検定およびTukey 検定で行った。 なお本文中での平均值の差の有意性は、95\%以上の有意 性のあるものに限って表記した。

表 1 . 血液検査項目および方法

\begin{tabular}{|c|c|c|c|c|}
\hline 検 査 項 目 & 略 & 法 & $\begin{array}{l}\text { 測定 } \\
\text { 器械 }\end{array}$ & 測 定 \\
\hline 血 球 数 & & 自動血球計数器 & $\mathrm{D}$ & \\
\hline 血色 素 量 & $\mathrm{Hb}$ & " & $\mathrm{D}$ & \\
\hline 血 球 容 積 比 & $\mathrm{Ht}$ & 毛 細 管 法 & & \\
\hline トリグリセライド & T G & 酵素 法 & A & ユニキットT $\mathrm{T}^{11}$ \\
\hline 遊 離 脂 肪 酸 & F F A & " & $\mathrm{C}$ & $\mathrm{NEFAザイムー} \mathrm{S}^{21}$ \\
\hline リ ン 脂 筫 & P L & $"$ & $\mathrm{C}$ & P Lザイム2) \\
\hline 総コレステロール & $\mathrm{TC}$ & $"$ & A & ユニキット・コレステロールE ${ }^{11}$ \\
\hline 遊離コレステロール & $\mathrm{F} \mathrm{C}$ & " & $\mathrm{C}$ & フリーコレステザイム2) \\
\hline 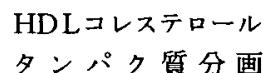 & HDL C & 七ル" & A & ユニキット HDL $-\mathrm{C}^{11}$ \\
\hline $\begin{array}{l}\text { アスパラギン酸アミ， } \\
\text { トランスフェラーゼ }\end{array}$ & $\begin{array}{c}\text { A S T } \\
(\mathrm{GOT})\end{array}$ & UVレート法 & $\mathrm{B}$ & イアトロファインGOTレート3) \\
\hline $\begin{array}{l}\text { rグルタミルトランス } \\
\text { ペ プチターゼ }\end{array}$ & $\gamma \mathrm{GTP}$ & $\gamma$ グルタミル $\mathrm{P}=$ トロアニリド基質法 & $\mathrm{B}$ & イアトロファインケ GTPレート3) \\
\hline $\begin{array}{c}\text { アルカリ性 } \\
\text { フォスファターゼ }\end{array}$ & A L P & 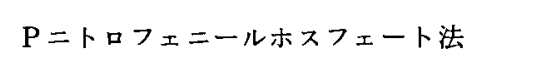 & A & ユニキットレート $\mathrm{AL} \mathrm{P}^{31}$ \\
\hline 総ビリルビン & Bil & 安定化ジアゾニウム塩法 & $\mathrm{B}$ & エスパT $\mathrm{B}^{4)}$ \\
\hline 尿 素 室 素 & B UN & ウレアーゼUV法 & $\mathrm{B}$ & イアトロファインUNレード' \\
\hline クレア千 = ン & Cre & Jaffe 法 & B & イアトロファインC R Eレード) \\
\hline$\alpha \Im ミ ラ-セ ゙$ & Amy & $\mathrm{G}_{5}-\mathrm{CNP}$ 法 & $\mathrm{B}$ & イアトロファインAMYレート3) \\
\hline 膵 リ パ & Lip & 1, 2-ジリノレオイルグリセロール基質法 & B & イアトロファイン L P レート ${ }^{33}$ \\
\hline グルコース & Glu & グルコース・オキシダーゼ法 & $\mathrm{A}$ & ユニキットレートグルコース ${ }^{11}$ \\
\hline
\end{tabular}


表 2 . 白浰、下淿㧍よひ健康な黒毛和種子牛の血液検查成䋖

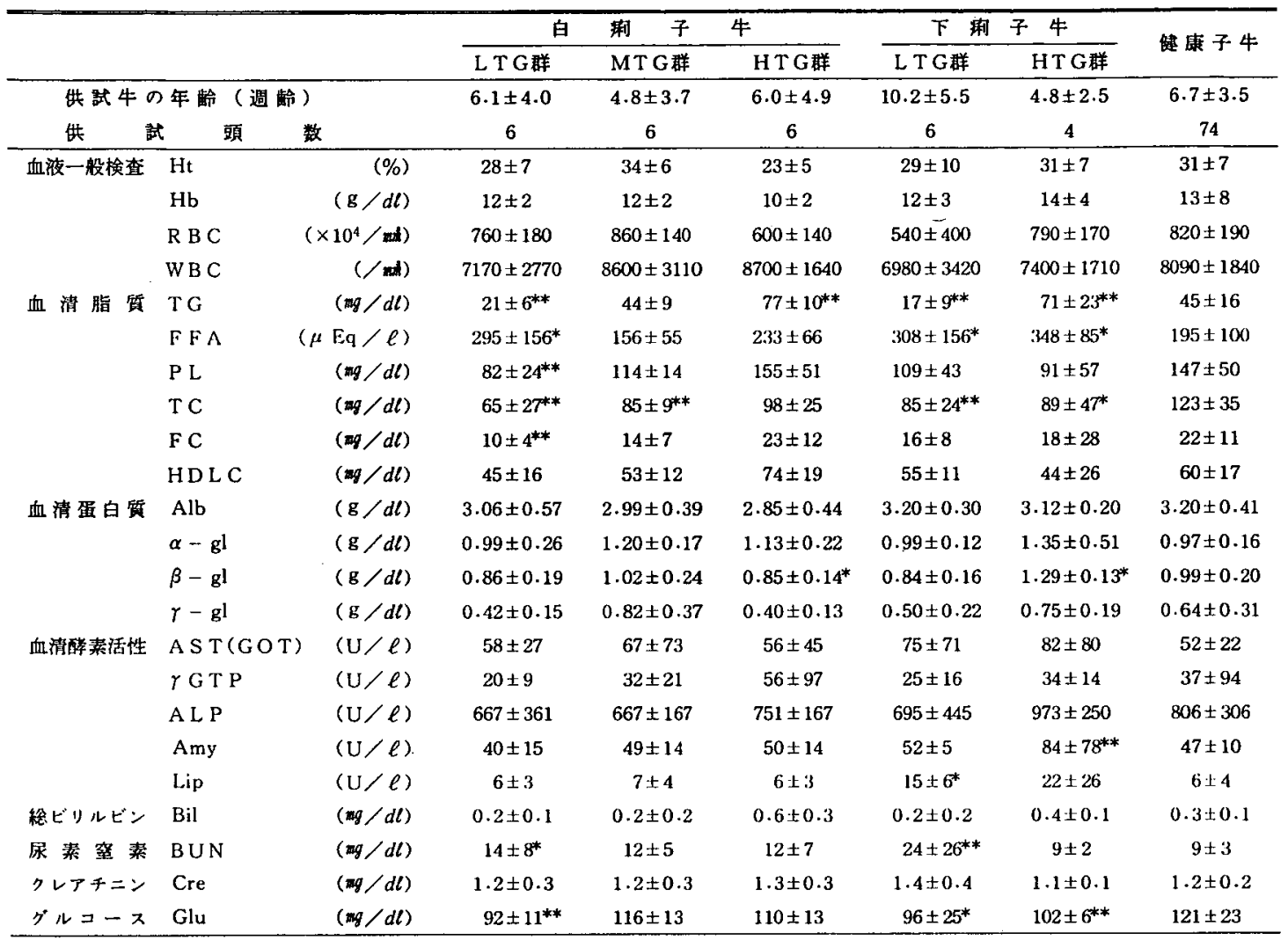

健康子牛に対寸る有意性 : * ; $\mathrm{p}<0.05 、 * * ; \mathrm{p}<0.01$

\section{成 績}

\section{1. 白㢉子牛の血夜検查成續}

白痢の18頭を T Gの濃度により 3 群に分類したものと、 健康子牛74頭の血液検查結果の平均值および標淮偏差は 表 2 に示した。MTG群の6 頭では、総コレステロール

（T C）が低值を示した他は、健康子牛と差が認められ なかった。L T G 群の 6 頭では、りン脂質 $(P \mathrm{~L}$ ）、T C、 遊離コレステロール（F C) の脂質成分とグルコース（Glu） が低值を示し、遊離脂肪酸（F F A）および尿素窒素 （BUN）が高值を示した。H G G群の 6 頭は、健康牛 と差が認められなかった。これらの白痢子牛は、全頭、 利胆放および抗生物質を主とした治療で 1 週間以内に治 漓した。

\section{2.下痢子牛の血液検査成續}

下浰の10頭を T Gの濃度により 2 群に分類したものの 血液検查結果の平均值と標準偏差は表 2 に示した。L T G群の 6 頭では、T Cおよび Glu が低值、F F A、B U N、アルカリ性フォスファターゼ（AＬＰ） および Lip
が高値を示した。H T G 群の 4 頭では、T Cおよび Glu が低值を、F F Aおよびアミラーゼ（Amy）が高值を 示し、Lip は個体差が大きかった。これら10頭の下瘌症 子牛のうち、T Gが $105 \mathrm{mg} / d \ell$ 最高值を示した 1 頭は発 育不良に宿ったが、他の 9 頭は止瀉剤および整腸剤を主 とした治潦で 1 週間以内に治痹した。

\section{3. 出血性下媊子牛の血液検查成樍}

初診時に出血性下浰を示した 3 頭の血液検查結果を表 3 に示した。症例Aは、第 2 病日から裏急後重および為 膜の排出を継続し、下痳が止まらず第13病日に管死した。 初竞時の血液検查では、T Gおよび Glu が高值を示し、 T C、アルブミン（Alb）が低值を示した。症例Bは、 糞便検查でュクシジウム症と診断され、サルファ剤を主 とした治療により腸出血は停止したが、軟便ないし下峲 便の状態が長期にわたって継続し、発育不良に陥った。 初診時の血液検查では、 T G、F F A、BUN、クレア チニン（Cre）およびLipが高值を示し、P L、T C、 F C、HDLコレステロール (HDL C )、Alb および 
Gluが低值を示した。 症例C注、10週龄の 雌で、4 日前から下 渿をしているとの臬 告で初診し、出血性 下㾥便が認められ、 蕒便検查によりコク シジウム症と診断さ れ、サルファ剤を主 とした治療により、 腸出血注第 3 病日に 停止した。しかし、 その後長期にわたっ て下峲ないし軟便を 繰り返したので、第 3 病日以降連続して 採血を行い、その検 查結果の一部を表 3 および図1に示した。 第 3 病日の血清は乳 濁し、血清脂質では $T G 、 F F A 、 P L 、$ F C、血清蛋白質で は $\alpha$ グロブリン $(\alpha-$
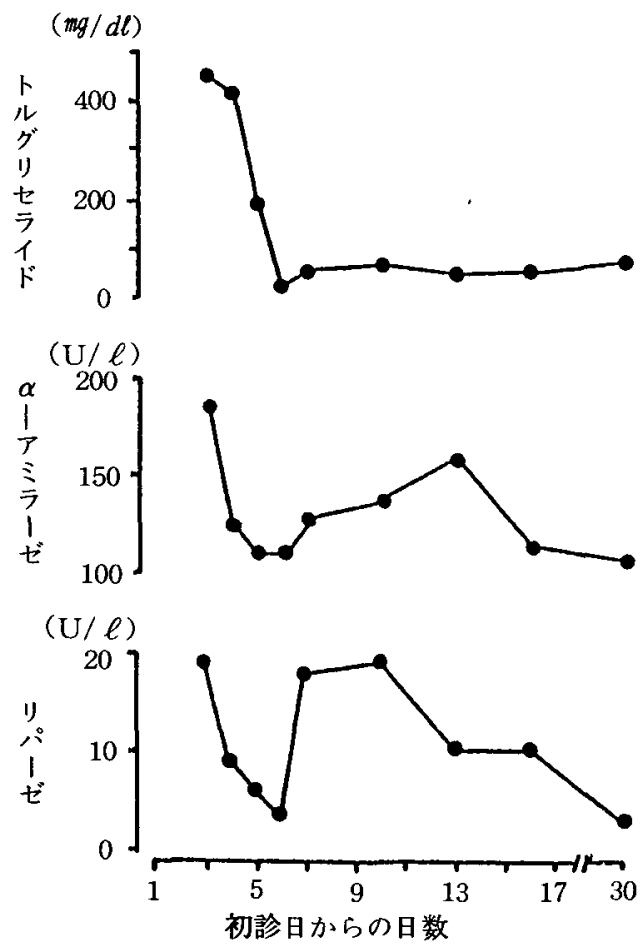

図 1 . 症例Cの主な血液成分の経日変化 gl）、血清酵素活性值ではアスパラギン酸アミノトラ ンスフェラーゼ（AST）、Amy、Lip、総ビリルビン （Bil）、BUN等が各々高值を示した。Fredrickson のリポタンパク分類では 5 型高リポタンパク血症に分類 された。

この子牛は、第 6 病日には Amy 、Lip 活性值をはじ め、T G、F F A $, \mathrm{P} \mathrm{L} 、 \mathrm{~F} \mathrm{C} 、 \alpha-\mathrm{gl}, \mathrm{GOT} 、 \mathrm{Bil} 、$ BUN等も、ほぼ正常值に回復した。しかし、第 7 病日 からは再び Lip 、Amy 活性值が増加し、それに伴って 他の検査項目もまた異常值を示した。第 9 病日には尿糖 が陽性となったので、第10病日に糖負荷試験を行ったと ころ、血糖の半減時間は40分であった。この子牛には、 保存療法を 2 週間続けたが泥状便を持続したので治療を 中止した。1 年後、この子牛の便性状は若干改善されて いたが、発育はやや不良であった。症例Cの母牛、両親 が共通の弟牛、および発症時期に同居していた哺乳子牛 の血液検查結果を表 4 亿示した。これらの牛は、いずれ も臨床的には健康であり、過肥は認められず、血液検查 成績にも一定の傾向はなかった。 
便は消化吸収能力を 越えた乳汁の摄取に より、脂肪含量の高 い未消化乳汁が排出 され白峲様を呈した ものと思われた。

よって、臨床的に は単純な白痢であっ ても、脂質代锹から みれば単一の病態で はないと思われ、そ の治療に際しては、 病態生化学的にもい くつかに分類して対 処する必要があると 考えられた。

いっぽう下浰子牛 においては、便の色 調が正常であること から脂肪の消化は正 常と考えられ、L T G群の 6 頭では T C およびGluが低值を 示し、腸管の吸収能 の低下による下痢と 考えられた。H T G

1) C牛の第 4 病日に採血

2) C牛の発症10力月後に採血

\section{考 察}

血清 T G は、腸から吸収された脂質の運搬体であるカ イロミクロン（CM）やそれが肝臟で代謝された超低密 度リポタンパク（V L D L ）の主な構成脂質であり2,14, 19)、腸管からの脂質吸収の指標とむなる。T T 濃度が健 康牛と同レベルであった 6 頭の白峲子牛では、 $\mathrm{T} C$ 䓜 值を示したが、これは週龄が健康群に比べて低いため221 の生理的な相違と思われる。L T G 群の 6 頭では F F A を除く全脂質成分が低值の傾向を示した。特に、T Gお よびGlu が低值を示していることから、哺乳量の低下あ るいは腸粘膜の異常による、腸管からの脂質および糖の 吸収の著しい低下のあることが示唆された。H T G 群の 6 頭では、T Gの著しい高值を示したほかは、各脂質成 分とも健康子牛と近似した值を示したが、これは腸から の脂質吸収が他群の子牛よりも多いことによると考えら れた。また、Glu 值が正常であることからも腸管の吸収 能は正常であると考えられたので、この高い T G 值は母 乳の過剩供給による脂質の吸収過剩によるものであり、
群の 4 頭では、T Gおよび Glu の值が正常であることか ら、腸管からの脂質および糖の吸収能は正常と考えられ た。T Gが高値を示したのは、F F A 除く他の脂質成 分が正常ないし低值であったことから、CMやV L D L の異化の低下 ${ }^{18)}$ が考えられた。その原因としては一部症 例で Lipが高値を示したことから、血中インシュリン袚 度の低下によるリポタンパクリパーゼ活性の低下等、膵 臓疾患との関連 $\left.{ }^{8}, 18\right)$ も考えられた。また、Amy および Lip の標準偏差が大きい原因は、一時的に異常な高值を 示した個体が各々1頭ずっあったためであるが、それら の個体は第 2 病日以降は異常が認められず、その原因は 不明であった。

出血性下痢子牛では 3 頭とも T Gが高值を示した。症 例 B は下浰の H T G 群と同㥞の血液所見であったが、低 タンパク血症を呈しており、腸管粘膜の損傷によるタン パク漏出の著しいことが示唆された。症例 $\mathrm{A} は \mathrm{~T} \mathrm{G}$ の高 值と T Cの低值から、CM、VLDLおよび中密度リポ タンパク（L D L）の異化の低下 ${ }^{18)}$ の可能性が示唆さ 
れた。Gluの高値は、裏急後重など重度の臨床所見を示 したことから、ストレスによるものと思われた。ALP は若龄牛ほど高值を示す22,24)にもかかわらず、A、B とも低値を示した。A L Pは小腸粘膜にも高い特異活性 を示す8.25)ので、小腸粘膜の脱落による活性の低下が考 えられた。

症例Cの第 3 病日の乳濁血清は 5 型高リポタンパク血 症であったので、CMおよびV L D Lによるもの3，8，14） と診断された。 5 型高リポタンパク血症の原因は、ヒト では榶尿病、膵炎、甲状腺機能低下、家族性疾患などが 挙げられている8，14)。このうち甲状腺機能低下は高コレ ステロール血症を伴う14，20)が、本症の T C は正常であ り、また触診上も甲状腺の異常は認められなかった。家 族性高脂質血症は、母牛および 1 年後に生まれた父母が 同一の弟牛の脂質成分が正常であったことから否定的で あった。また同一時刻に採血した同居子牛の検查では異 常が認められず、過肥もないことから食慨性の可能性も 否定的であった。第 9 病日以降に尿糖が認められたが、 第3病日の Glu は同一週龄の健康な牛の值と比較すると 著しく低く、その後も低值ないし正常值を示していたこ とから、真性糖尿病は否定的であった。ヒトの膵炎では、 急性期に Amy おうよび Lip 活性值の一過性の上昇があり、 4 日で低下した後、再度軽度の上䄯がある14)といわれて おり、実験的膵炎犬においても同様のことが認められて いる ${ }^{26)}$ 。本症例は Amy および Lip 活性值の変化が、第 3 病日以降についてはこれらのパターンと類似していた。 Amy 活性值は腸疾患等でも上昇するが、Lip 活性值は

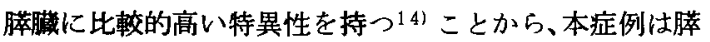
蔵酵素の血中への逸脱があるむのと考えられた。さらに $\alpha-\mathrm{gl}$ の増加があり、また各種血清酵秦の異常値を示 した時期が Amy および Lip 活性の変動と一致していた ことから、膵滕からの逸脱醉素による同時多発性急性炎 症、いわゆる多䑏器不全の状態にあった可能性が考えら れた。これらのことから本症例は急性膵炎と診断された。

以上のように、白痢や出血性下莉を含めた子牛の下痢 症においては、脂質代謝の低下したものと䒕進したもの のあることがわかった。T Gが低值を示す症例ではF F Aが高值を示し、エネルギーバランスが負の状態になっ て、体力的に消耗しているものと考えられた。いっぽう T Gが高值を示す症例では、白脷の場合は、母牛への濃 厚飼料多給等による泌乳量の増加が原因と思われる、脂 質の過剩給与のあることが示晙された。また白峲以外の 下峲では膵萑機能異常が関与した症例が含まれ、予後の 悪い傾向が認められた。これらの子牛の下痢症の病態の
把握および治療方針の決定に際して、TGおよび Lip を 測定することは有効な指標となると考えられた。

\section{文 献}

1 . Bitman, J., Wood, D. L. and Lefcourt, A. M. (1990). Rhythms in cholesterol, cholesteryl esters, free fatty acids, and triglycerides in blood of lactating dairy cows. J. Dairy Sci. $73: 948-955$.

2. Chapman, M. J. (1980). Animal lipoproteins : chemistry, structure, and comparative aspects., J. Lipid Res. $21: 789-853$.

3. Fredrickson, D. S., Levy, R. I. and Lees, R. S. (1967). Fat transport in lipoproteins- an integrated approach to mechanisms and disorders., N. Engl. Med. 276, 148-156.

4. Fujihara, T., Sasa, Y. and Isshiki, Y. (1987). Blood chemical analyses in sucrose-induced diarrhoeic calves after oral rehydration with either a glucose- glycine- electrolyte solution or a saline solution. Jpn. J. Zootech. Sci. 58: $60-64$.

5. Fujihara, T., Sasa, Y. and Isshiki, Y. (1987). The treatment of spontaneous calf diarrhoes via oral administration of electrolyte solution containing glucose and glycine. Jpn. J. Zootech. Sci. $58: 162-169$.

6. 平山寿一郎 (1992). 和牛子牛の下痢症一補液と断乳 療法, 家畜診療. $343: 15-22$.

7. 井上 亮, 後藤浩人, 小林隆之, 小屋正人,山科 淳, 斉藤才吉, 高橋公明, 吉田 登, 伊東金助 (1987). 子牛の低色素便排出の成因とその治療法について, 家畜診療. 286 : 9-16.

8. Kaneko, J. J. (1989). Clinical biochemistry of domestic animals. Fourth ed., Academic Press, Inc., New York. [久保周一郎,友田 勇監訳(1991)， 家畜臨床生化学, 第 4 版, pp. 116-125, pp. 356358 , pp. $411-421$, 近代出版, 東京]

9. 河西了吾 (1991). 和牛子牛の下峲症, 家畜診療. $342: 15-23$.

10. 北川政幸, 川島良治 (1981)，ヒッジおよびウシにお ける血墏脂質とグルコース含最の給慨による経時的 変化ならびに日間変動，日畜会報． $52 ： 483-485$.

11. 清宮直子, 井上定見, 宫地龍彦 (1991). 管内一農家 での黒毛和種における移行抗体量と子牛の下痢症に ついて, 家畜診療. $337: 35-41$.

12. Koiwa, M., Hatsugawa, A., Abe, T. and Minami, S. (1990). Therapeutic effects of electrolyte solution with oil emulsion on serious diarrhea in holstein calves. Jpn. J. Vet. Sci. $52: 639-641$.

13. 小久江栄一（1988）。下脷と補液, 家畜診療. 302 : $45-49$.

14. Medical Practice 編集委員会編 (1990). 臨床検查 ガイド，第 1 版，文光堂、東京.

15. 森田二郎, 土屋平四郎, 南高夫, 服部直彦(1984). 黑毛和種去勢牛の脂育過程に伴う血清脂質量の変化 並びに屠体成績との関係，鳥大農研報． $36: 19-27$.

16. 村山和哉 (1992) . 和牛子牛の下㾜症一異常乳質によ る下浰一, 家畜診療. $344: 5-12$.

17. 中根淑夫 (1988). 子牛の下痢症一原因，飼養管理を 主として一, 家畜診療. 302:33-44.

18. 及川真一, 生井一之 (1990). 高トリグリセリド血症 の病態, 内科. $66: 45-50$. 
19. Raphael, B. C., Dimick, P. S. and Puppione, D. L. (1972). Lipid characterization of bovine serum lipoproteins throughout gestaion and lactation., J. Dairy Sci. 56: 1025-1032.

20. 佐藤 繁, 富田和夫, 渥美孝雄 (1980). 高脂血症を 伴うウシの先天性甲状腺腫の 1 例について, 日獣会 誌. $158: 18-21$.

21. 佐藤輝夫 (1984).下蔽に䍜患した黒毛和種における 補液がその酸, 塩基および電解質に及ぼす影響, 家 畜診療. $257: 11-13$.

22. 高橋千賀子, 岡田啓司, 渥美孝雄, 平野哲夫, 高橋 一郎 (1992). 黑毛和種健康子牛の血清脂質を中心と した血液成分の加龄による変化. 東北家畜臨床研誌
$15: 9-14$

23. 高橋清治, 石田敏雄, 氏家 哲 (1991). 黑毛和種牛 の下浰多発放牧場における発生要因の分析と予防対 策, 家畜診療. $333: 13-18$.

24. 高橋清志, 平塚博之, 其田三夫, 黒沢 隆, 植田寿 恵弘, 箕輪 光, 小田勝一 (1982). 黒毛和種子牛の 哺乳期に㧍ける血液所見, 酪農学園大学紀要. 9 ： $449-463$

25. 友田勇 (1979). 臨床血液化学検查の考え方 $(\mathbb{X})$. V. 血液酵素，3.アルカリフォスファターゼ, 日 獸会誌. 32:93-103.

26. 森園 充 (1990). 膵炎 : 新版獣医内科学（安田純夫, 村上大藏監修), pp. 266-270, 文栄堂, 東京. 